\title{
ADVANCEMENT OF TOOLS SUPPORTING IMPROVEMENT OF WORK SAFETY IN SELECTED INDUSTRIAL COMPANY
}

\author{
Anna GEMBALSKA-KWIECIEŃ \\ Silesian University of Technology
}

\begin{abstract}
:
In the presented article, the advancement of tools to improve the safety of work in the researched industrial company was taken into consideration. Attention was paid to the skillful analysis of the working environment, which includes the available technologies, work organization and human capital. These factors determine the development of the best prevention activities to minimize the number of accidents.
\end{abstract}

Key words: advancement of tools in safety management, safety engineering, human factor

\section{INTRODUCTION}

At the turn of the last few decades, accident prevention and accident investigation have changed significantly. Accidents that were previously the result of a fatal and unpredictable coincidence today are perceived as the result of mistakes made by people at various levels of company activity - from management through supervision to a serial employee. At present, most accidents are identified and recorded. Companies have a very important task to skillfully analyze the working environment, which includes the available technologies, the organization of work and human resources. These factors determine the development of the best prevention activity to minimize the number of accidents $[2,3,4]$.

The analysis conducted by the International Labor Organization shows that annually in the world there is an average of about 270 million accidents including 350,000 of lethal accidents. European Union statistics show that during the year four in a thousand of workers suffer a lethal accident. In Poland five in a thousand workers suffer a lethal accident [5, 7].

The premise of choosing the topic of the article was to point out that the conscious management of factors directly affecting work safety (i.e. technology, organization, people) at all levels of the company's activity is crucial to improving accident prevention.

\section{CHARACTERISTICS OF THE RESEARCH SUBJECT}

The object of the research was an industrial company, which is an international corporation located in the Silesia Economic Zone. The main profile of the company's activity is the production of pre-insulated pipes, fittings, joints of various dimensions used in heating and cooling, among others, due to the temperature range from $-200^{\circ} \mathrm{C}$ to $+250^{\circ}$ C. The company supplies piping systems for the transport of oil and gas as well as to the shipbuilding industry. The advantage of these pipes is the fast installation and long ser- vice life. The plant employs full-time steel workers and seasonal workers who work in the summer, when the company receives the most orders. Work in the company takes place in a three-shift mode. The company has an occupational health and safety department that is outsourced. The company is certified to ISO 9001 (Quality Management System standard) and ISO 14001 (Environmental Management System standard ). The company consists of a production hall, administrative building and warehouse [1].

\section{ACCIDENTS AT WORK IN THE SURVEYED MANUFACTURING COMPANY}

The analysis covers accidents that occurred in years 2010-2012. Accident records contain a total of 45 accident events occurring within 3 years. The analyzed postaccidental documentation includes:

- accident protocols,

- statistical accident cards,

- protocols from interviews: the injured and witnesses of accidents.

Between 2010 and 2012, 906 people were employed in the company. In 2010, the workplace employed 296 people, of which fourteen were injured at work. In 2011 the number of employees in the company increased to 297, of which as many as eighteen were injured in the accident. However, in 2012 there was a significant increase in the number of people employed in the company, which rose to 313 employees. And the number of accidents has dropped to 13 accidents a year. The downward trend in the surveyed plant overlaps with the situation in the country, where the number of accidents has also decreased [1].

Analysis of statistical accident and accident records from the surveyed company from the three-year period 2010-2012 showed that the accident rates in 2010-2012 are significantly higher than national ones. The highest value was achieved in $2011-61$, in 2012 the index was 42 [1, 6]. 


\section{THE CAUSES OF ACCIDENTS AT WORK IN THE SELECTED COMPANY}

The analysis of statistical accidents cards and accident reports shows that the most common cause of accidents at work is an astonishment of an unexpected incident, which accounts for $26 \%$ of all causes of accidents. Next is not paying sufficient attention on the work being done $23 \%$. According to the data, workers with an internship up to $47 \%$ of all victims last year are most likely to experience accidents due to lack of experience and the inability to anticipate the consequences of making a decision while doing their job. The third group with $13 \%$ score is another reason. Improper handling of the limbs in the danger zone reached $11 \%$. Another cause is improper grasping, keeping material factor, $8 \%$ [1].

Based on the collected data from the accident investigation records of the investigated company, there were 76 causes for 45 accidents at work in the three years 20102012. The following technical, organizational and human causes have been identified following the TOL methodology analysis (Table 1).

As many as 71 reasons concerned the human factor, 4 were related to the organizational factor, and only 1 was technical.

According to the analysis of collected data, $59 \%$ of accidents at work is a result of improper employee behavior. The second cause with the result of $20 \%$ is the lack or misuse of material factor. Inappropriate, arbitrary, employee behavior occupies the third position with a score of $12 \%$. Another group of causes is $3 \%$, which includes improper organization of the workplace and improper organization of work. Up to the last group of causes with a score of $1 \%$ include the employee's psychophysical status, non-use of protective equipment and improper material condition. In total, human factor causes $93 \%$ of all accidents at work. On the other hand, organizational reasons account for $6 \%$ of all causes and technical $1 \%$ [1].

\section{IMPROVING ACCIDENT PREVENTION IN THE SELECTED COMPANY}

In the studied company there is an accident prevention applied and it is consistent with applicable regulations and standards. The scope of preventive activities is outsourced to an outside company that oversees all activities related to improving occupational safety. However, lack of continuous supervision requires taking additional preventive action by the employer. After analyzing the research, it was found that the improvement of some technical, organizational and human aspects could improve the safety of work in the company. Therefore, specific changes in accident prevention of the investigated company are proposed, as set out below.

The first proposal for preventive solutions is the introduction of a contingency sheet. This sheet was created to involve all employees in improving health and safety. It not only reports the occurrences of accidents but also denotes potential accident events. It is often the case that an employee, noticing a dangerous situation, does not always report to the supervisor. When it is possible to report this status and the number of reported reports will result in the employee assessment, all possible tools for improving safety will be used. Employees who perform standard work are quick to spot any danger. The introduction of an intervention sheet will also allow for the creation of a database containing places and situations where an accident may occur - they will allow for more accurate accident prevention. The sheet contains all the information about the potentially fatal event. The first page defines when employee's work situation has occurred, where it occurred and what was a direct threat. The second page begins with the use of the " 5 WHY" method, which aims to identify the cause of the source of the hazardous event and how to eliminate the threat. It also includes information on who will be responsible for the implementation of these activities along with the planned deadlines for their completion.

Table 1

Causes of accidents at work according to the TOL classification over a period of 3 years
I. Technical causes
1. Improper condition of the material factor
II. Organizational causes
1. Improper organization of work
2. Improper organization of the work station
III. Human causes
1. Incorrect employee behavior
2. Inappropriate, arbitrary employee behavior
3. Inadequate psychophysical condition of the employee
4. Lack of or improper use of the material factor 
The second prevention proposal is to create a health and safety system for the selected production area. The system consists of appointing one day a week, in which the supervisor of a given area performs checks according to the control sheet. This sheet contains questions about employee awareness of the risks posed by their work positions and their compliance with safe work practices. This also applies to the technical condition of tools, the way of evacuation routes and fire protection measures. Introducing such a weekly control system will allow you to maintain a safe working environment, and identify irregularities quickly eliminated. In addition, it also introduces the motivation to work safely for employees who know that there is a continuous workplace control system.

Another suggestion is to introduce an employee safety and health plan. The sheet contains the topic that was raised by the supervisor, the date of the interview, and the signatures of the participating employees. This sheet is a proof of an employee's participation in preventive actions and a list of events that occur in a given area of work.

The next proposal to improve workplace safety is the introduction of PN-N-18001:2004. The health and safety management system described in this standard is based on the classic quality management cycle, the philosophy of continuous improvement in accordance with the Deming Wheel. At the same time it is recommended to create a safety and health station at the site. It will streamline monitoring, emergency response and permanent work safety controls.

The analysis of the health and safety situation of the plant shows that employees are largely unaware of their scope of work. It is therefore advisable to carry out inspections and to clarify responsibilities at workstations. At the same time, once the activity has been carried out, the employees should be re-acquainted with their scope of work. Each change should be made in writing to the employee and should be confirmed by its signature.

Another suggestion for improving security is the introduction of a mentor system. A mentor system is characterized by the fact that, in the event of a change of workplace by one employee or his promotion, he assumes responsibility for the employee who replaces him. He teaches the activities and controls until the change is aware of all aspects of work - both safety and quality.

It is recommended to implement the " $5 \mathrm{~S}$ " system, which says that all work tools have a marked place at the work station and that their position is respected. In addition, by selecting and sorting on the bench, there are only necessary things to do the job. It is also recommended that you mark the places where you are most likely to be at work.

It is proposed to implement a semi-annual evaluation system, where the main component will be the assessment of compliance with safe work practices.

Another recommendation is to choose an employee for the Social Labor Inspector who will directly supervise the workplace to ensure safe and hygienic working conditions.

It is proposed to implement a bonus for non-accidents work for a period of calendar year, which will be an additional motivation for safe work.

It is also proposed to prolong the training period for new staff in order to properly control the activities of the workplace. Employees often need more time to know what they are doing and to learn how to deal with non-standard situations. It is also advisable to keep a supervisor in check during the probationary period, which will supervise the work of the newly recruited employee and intervene in emergency situations, eliminating the risk of an accident.

It is suggested that employees participate in improving their work safety by allowing them to submit ideas for improving safety, work organization, technical solutions and putting them in the box of ideas. The best idea will be announced in the workplace and awarded with a prize.

The survey shows that the training is conducted in a very general way, therefore it is recommended that training be conducted in terms of workplace hazards. Each time the training should be completed with a test to verify the knowledge gained by the participants $[1,6]$.

\section{RESEARCH RESULTS AND CONCLUSIONS}

As a result of the research, the following conclusions were obtained $[1,6]$ :

1. Based on the documentation of the company, it was stated that:

- most of the accidents took place during the spring and summer season when the company employs seasonal workers during a period of increased demand for finished products,

- the most common cause of the accident was an employee's improper behavior,

- there was a close relationship between the age and the length of work, and the number of accidents,

- it has also been shown that the day of the week and the time of the year have an impact on the occurrence of accidents at work,

- the event that caused most injuries during an accident was contact with a sharp object,

- the greatest number of accidents are injuries to the hands and fingers,

- the most common injuries are cut wounds.

2. Conclusions of the survey conducted among employees:

- the training provided was mostly evaluated as interesting, motivating for safe work; however, most respondents suggested that training is too general,

- most of the time, employees are under constant supervision; however, there are cases in which employees are left without control,

- $42 \%$ of employees are not aware of the consequences of their mistakes,

- according to the respondents, the greatest impact on the occurrence of an accident is lack of work experience, time pressure, lack of knowledge of hazards and strong or long-lasting stress,

- research shows that almost half of employees do not know the scope of their responsibilities,

- $32 \%$ of employees themselves decide when to use personal protective equipment.

The conducted research allowed to show weak points in the applied accident prevention of the company, and thus to develop changes in the organization and under the prevailing working conditions to improve them. It has also been found that reducing the number of accidents at work is possible as a result of the correct and reliable identification of the causes of the accidents and, consequently, the negative impact of the negative technical, organizational and human factors. 


\section{ACKNOWLEDGEMENTS}

This article was prepared within the statutory research titled "Methods and tools for improving products and services on the selected examples" work symbol 13/030/BK_17/0027 performed at Silesia University of Technology, Institute of Production Engineering.

\section{REFERENCES}

[1] Internal documents of the researched company, Gliwice, 2013.

[2] A. Gembalska-Kwiecień, "Innovative forms supporting safe methods of work in safety engineering for the development of intelligent specializations", Management Systems in Production Engineering, vol. 24, no. 4, pp. 268-273, 2016.

[3] A. Gembalska-Kwiecień, Czynnik ludzki w zarzqdzaniu bezpieczeństwem pracy w przedsiębiorstwie. Wybrane zagadnienia. Gliwice: Wydawnictwo Politechniki Śląskiej, 2017.

[4] J. Lewandowski, Zarzq̨dzanie bezpieczeństwem pracy w przedsiębiorstwie. Łódź: Wydawnictwo Politechniki Łódzkiej, 2000.

[5] L. Pietrzak, Analiza wypadków przy pracy dla potrzeb prewencji. Warszawa: Państwowa Inspekcja Pracy, Główny Inspektorat Pracy, 2007.

[6] D. Sitko, „Analiza i ocena przyczyn wypadków w przedsiębiorstwie przemysłowym", M.S. thesis, Faculty of Organization and Management, Silesian University of Technology, Zabrze, 2013.

[7] Wypadki przy pracy 2001-2013, Główny Urząd Statystyczny, Warszawa, 2014.

\section{dr Anna Gembalska-Kwiecień}

Silesian University of Technology

Faculty of Organization and Management

Institute of Production Engineering

ul. Roosevelta 26, 41-800 Zabrze, POLAND

e-mail: Anna.Gembalska-Kwiecień@polsl.pl 